\title{
The effects of agroecological farming systems on smallholder livelihoods: a case study on push-pull system from Western Kenya
}

Raffaele D'Annolfo, Barbara Gemmill-Herren , David Amudavi , Hudson W. Shiraku, Mariacristina Piva \& Lucas A. Garibaldi

To cite this article: Raffaele D'Annolfo, Barbara Gemmill-Herren, David Amudavi , Hudson W. Shiraku , Mariacristina Piva \& Lucas A. Garibaldi (2020): The effects of agroecological farming systems on smallholder livelihoods: a case study on push-pull system from Western Kenya, International Journal of Agricultural Sustainability, DOI: 10.1080/14735903.2020.1822639

To link to this article: https://doi.org/10.1080/14735903.2020.1822639

\section{0.}

\section{Submit your article to this journal $x$}

Щ Article views: 77

Q View related articles $\sqsubset$

View Crossmark data $[\pi$ 


\title{
The effects of agroecological farming systems on smallholder livelihoods: a case study on push-pull system from Western Kenya
}

\author{
Raffaele D'Annolfo (D) ${ }^{a}$, Barbara Gemmill-Herren (D) ${ }^{b}$, David Amudavic, Hudson W. Shiraku', \\ Mariacristina Piva (iD) ${ }^{d}$ and Lucas A. Garibaldi (iD)
}

${ }^{a}$ Doctoral School on the Agro-Food System (Agrisystem) of the Università Cattolica del Sacro Cuore, Piacenza, Italy; ${ }^{b}$ World Agroforestry Centre, Nigiri, Nairobi, Kenya; 'Biovision Africa Trust, Nairobi, Kenya; ${ }^{\mathrm{d} D e p a r t m e n t ~ o f ~ E c o n o m i c ~ P o l i c y, ~ U n i v e r s i t a ̀ ~}$

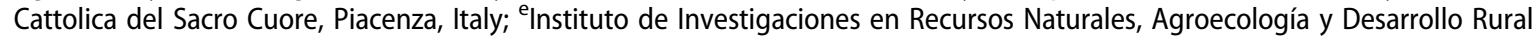
(IRNAD), Sede Andina, Universidad Nacional de Río Negro (UNRN) and Consejo Nacional de Investigaciones Científicas y Técnicas (CONICET), San Carlos de Bariloche, Río Negro, Argentina

\begin{abstract}
There is a need for scaling-up agroecology to promote sustainable agriculture at global level. Although, recent studies show that agroecological approaches can achieve both high yields and profits compared with conventional systems, the performance of other socioeconomic indicators remains unknown. This study has two objectives (i) identify the main characteristics of small-scale producers who represent the target-groups of the SDG 2; (ii) provide a comparison between pushpull and conventional farming systems of maize production to explore and possibly implement sustainable systems. In collaboration with Biovision Africa Trust, a participatory assessment framework was implemented in Western Kenya. Twentythree farmers were selected and data were analysed showing that the push-pull contributes to social/cultural and natural/ecological capitals. In particular, push-pull farmers are more focused on socially oriented groups (75\%); moreover, they cultivate smaller plots ( $1.9 \mathrm{ha}$ ) compared to conventional farmers ( $3.1 \mathrm{ha})$ without showing a reduction in profitability. The benefits of adopting push-pull system indicated by farmers (e.g. diminished Striga weed) are consistent with the advantages reported in relevant scientific literature. Considering the explorative nature of this study, the article makes a key contribution by pointing towards important questions for future research on agroecology in Sub-Saharan African countries.
\end{abstract}

\section{KEYWORDS}

Agroecology; push-pull system; integrated pest management; participatory assessment; sustainable livelihood framework; Kenya

\section{Introduction}

Concern over the ecological footprint of conventional farming systems highly dependent on external inputs, such as fertilizers, herbicides and genetically modified organisms, has continuously grown in the last decade (Balmford et al., 2018; Foley et al., 2011; Gonthier et al., 2014; Pretty, 2008). The Global Biodiversity Outlook 4 reports that agriculture is the driver for approximately $70 \%$ of the projected loss of terrestrial biodiversity (SCBD, 2014). Around 50\% of areas used for agriculture show high levels of water stress, resulting in the serious depletion of rivers and aquifers (Poore \&
Nemecek, 2018; Xinchun et al., 2017). As a result, the agreed United Nations 2030 Agenda for Sustainable Development underlines in Goal 2 the urgent need to make a wholesale transition to sustainable systems of food production aimed at achieving food security, as well as implementing resilient agricultural practices that strengthen capacity for adaptation to climate change (UN, 2015).

Numerous publications highlight that a transition towards agroecology can represent a path to achieving multiple Sustainable Development Goals, as it is based on the promotion of ecological principles and

CONTACT Raffaele D'Annolfo dannolfo@hotmail.it $\Theta$ Doctoral School on the Agro-Food System (Agrisystem) of the Università Cattolica del Sacro Cuore, via Emilia Parmense 84, PC 29122, Piacenza, Italy

๑ 2020 Informa UK Limited, trading as Taylor \& Francis Group 
human and social values along entire agrifood value chains (FAO, 2018; Francis et al., 2003; Pengue et al., 2018; Wezel et al., 2018). Agroecological approaches require a knowledge-intensive process, which often combines local traditional farming practices and modern science, allowing the optimal management of nature's ecological functions and biodiversity in the agroecosystem in order to: (i) reduce dependency on external inputs; (ii) improve farming system performance (Duru et al., 2015). When this occurs, a variety of benefits such as enhanced yields, improved food security, increased social cohesion and reduced greenhousegas emissions are perceived at different scales (Altieri, 2002; De Schutter, 2010; Pretty et al., 2006).

Recent studies emphasize that the quantitative socioeconomic effects of agroecological approaches are still poorly documented, particularly in scientific literature (D'Annolfo et al., 2017). In light of the fact that about $65 \%$ of the extreme poor (living on less than $\$ 1.90$ a day) are employed in the agricultural sector it is of paramount importance to provide evidence on the effects of agroecological farming systems on small-scale producers (Castañeda et al., 2018; Graeub et al., 2016). Therefore, the main purpose of this study is to challenge assumptions on possible ways to assess the effects of agroecological approaches by providing both qualitative and quantitative results, and to suggest connections between these and the sustainable livelihood (SL) frameworks of small-scale farmers that merit further investigation.

The proposed methodology adopted in this study is based on the participatory assessment framework proposed by Garibaldi et al. (2017), adapted for assessing simultaneously the ecological and socioeconomic effects of competing push-pull and conventional farming systems in Western Kenya. The research questions are listed as follows: (i) is the push-pull system a suitable solution to resource-poor farmers in Western Kenya? (ii) can the push-pull system deliver both improved socioeconomic and environmental outcomes in comparison to the monocropping system of maize production?

\section{Background information}

\subsection{Rural poverty in Kenya}

During the 1960s the Green Revolution was partially successful in Asia where the dramatic increase in rice and wheat production prevented massive food shortages and contributed to a substantial reduction in poverty (Hazell, 2009). The Green Revolution was characterized by technological transfer including high-yielding varieties, chemical fertilizers and the mechanization of the agricultural sector (Hazell, 2009). In Africa, the Green Revolution did not have the same success (De Groote et al., 2005). Despite Kenya experiencing an increase in maize production mainly led by large-scale commercial farms, in the 1980 s continuously increasing maize yields stalled (Hassan, 1998). The rapid population growth associated with the decline in food availability caused an increased risk of famine in the country (De Groote et al., 2005).

Agriculture is the main sector of the Kenyan economy, contributing to $35 \%$ of GDP (WB, 2019). Kenyan agriculture is currently facing several issues such as low productivity, poorly developed markets and climate change (FAO, 2014; Kassie et al., 2018). In 2017, the amount of maize produced per hectare was $11 \%$ lower than that of 2010 (FAO, 2019a). The introduction of subsidies for maize grain imports and derivatives has pushed down the price of maize showing a decrease of between $10 \%$ and $15 \%$ during the first quarter of 2018 (FAO, 2019b). Furthermore, the prolonged dry spell in 2017 caused moisture stress and wilting of crops resulting in a fall in cereal production of $18 \%$ - the average level of the previous five years (FAO, 2019b). According to the World Bank, $36.8 \%$ of the Kenyan population was living on less than $\$ 1.90$ a day (WB, 2019). Overall, the number of people in need of humanitarian assistance in the country was about 2.35 million: high food insecurity levels persist, especially in pastoral and agro-pastoral areas (FAO, 2019b).

\subsection{Push-pull cropping system in Western Kenya}

In Western Kenya, 77\% of the population relies on cultivation, forestry, fisheries and livestock as their main source of income (Kassie et al., 2018). About $76 \%$ of cultivated land is infested by Striga weed which causes grain yield losses up to the totality of the harvest, accounting for approximately $\$ 40.8$ million lost (Kanampiu et al., 2002; Midega et al., 2015) (Figure 1).

In this context, the push-pull system acquires great relevance as it offers an agroecological approach to dealing with major constraints in grain production (Amudavi et al., 2009a, 2009b; Kassie et al., 2018; Khan et al., 2016). The push-pull system has been largely applied as a farming approach to growing 


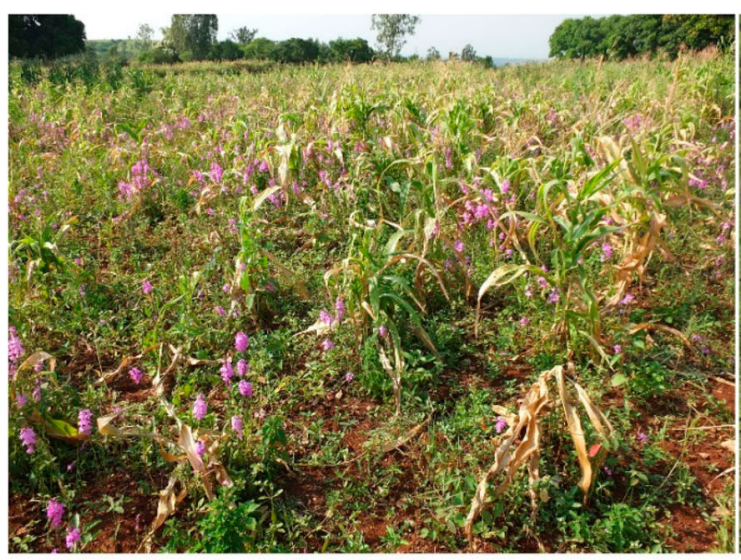

(a)

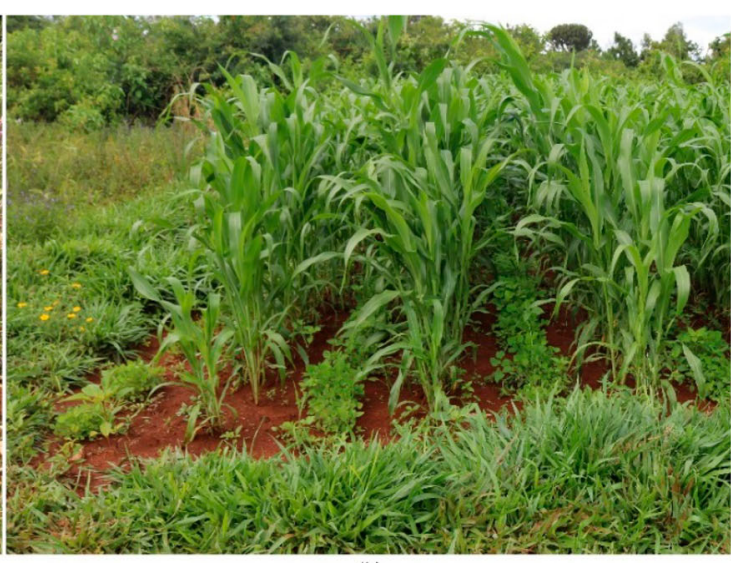

(b)

Figure 1. (a) Maize field infested by Striga weed in the Maseno area; (b) Maize field cultivated by adopting push-pull system.

cereals in an integrated ecological manner in SubSaharan Africa (SSA) where maize and sorghum play a key role in smallholder farmers' diets (Chepchirchir et al., 2018; Khan et al., 2011; Pickett et al., 2014, 2016; Pretty \& Bharucha, 2015). From a theoretical point of view the push-pull system is based on the use of two companion plants which release semiochemicals: (a) the companion plant in between the main cereal crop repels 'push' insect pests such as stemborers from the main crop and also produces chemicals which inhibit Striga attachment to maize roots; (b) the companion plant around the main cereal crop 'pull' insect pests away from the cereal field (Khan et al., 2008). While it has been discovered that different companion plants had further benefits in terms of suppression of Striga weed, our case study focused on the combination of Desmodium intortum (commonly known as Greenleaf) and Napier grass, acting as 'push' and 'pull' intercrops, respectively (Kebede et al., 2018) (Figure 1). In addition to controlling pests and Striga parasitic weed, the considered push-pull system has several advantages: (i) it provides enhanced fertility through nitrogen fixation and microbial activity in the soil; and (ii) increases fodder production with low water and nutrient requirements (Amudavi et al., 2009a, 2009b; Midega et al., 2015).

\section{Materials and methods}

\subsection{A participatory assessment framework for building evidence}

As underlined by Schader et al. (2014) and Garibaldi et al. (2017) different frameworks to assess sustainability already exist; however, the majority of them does not cover the ecological, social and economic dimensions of family farms simultaneously and are difficult to adapt to contrasting local circumstances. The dimensional metric, often used in assessing agricultural performance, based only on yield and profitability ignores the negative consequences (e.g. soil erosion) and the trade-offs across multiple dimensions of human livelihoods (e.g. capital endowments), as well as failing to account for the various aspects of sustainability (Speelman et al., 2007). Therefore, an alternative methodology should incorporate socioeconomic effects (e.g. food security) while measuring ecosystem service outcomes (e.g. biodiversity) (Berghöfer et al., 2018).

As highlighted by Garibaldi et al. (2017), an effective methodology for building the evidence based on alternative farming systems needs to be founded on the following assumptions: (i) consider farming systems as integrated socioecological systems; (ii) incorporate an ecological, social and economic dimension; (iii) integrate both quantitative and qualitative techniques; (iv) promote the participation, learning and empowerment of stakeholders; ( $v$ ) be a simple self-assessment tool which considers multilevel interactions; (vi) allow comparisons between different farming systems. The suggested methodology should consist of four steps: (1) definition of conventional and alternative farming systems; (2) selection of indicators; (3) processing and analysis of data; (4) actions aimed to improve the selected farming systems (Garibaldi et al., 2017).

Interaction between farmers and researchers is a central tenet of agroecology. According to Altieri 
and Masera (1993), a comprehensive reframing of a development strategy in rural areas is based on a bottom-up approach. Therefore, farmers must be involved from the beginning of the assessment exercise with the specific objectives of empowering them, favouring the co-creation of knowledge and its dissemination among all stakeholders: (a) policymakers (e.g. governmental agencies); (b) academia (e.g. universities); (c) civil society (e.g. grassroots movements) (Mbeche Nyang'au et al., 2018).

\subsection{Adaptation of the framework into a protocol to assess push-pull farming performance}

The above framework was adapted and implemented in collaboration with Biovision Africa Trust (BvAT), a not-for-profit organization, to assess the performance of different farming systems. Western Kenya represents one of the pioneering places in SSA where the push-pull system was introduced in 1997. It was developed by scientists at the International Centre of Insect Physiology and Ecology, in Kenya and Rothamsted Research, in the United Kingdom (Kassie et al., 2018). In 2009, approximately 25,000 farmers were using the push-pull system in Western Kenya and almost 30,000 in the country as a whole (Khan et al., 2011). Smallholder farmers face considerable difficulties in accessing credit, as banks are often reluctant to lend money to them due to inadequate collateral and lack of information. In particular, women farmers face more significant disadvantages than their male counterparts - they have less access to productive assets and market information, and the majority of them remain illiterate, thus limiting their efforts to farm for economic gain. BvAT supports push-pull system dissemination among poor farmers, especially women and youths, through the provision of field training programmes and learning materials (e.g. print and broadcast) and works to address policy constraints that can enable the scaling-up of agroecological approaches in the country.

The fieldwork to conduct data collection was undertaken during the first semester of 2017 in Kisumu County, close to the city of Maseno (Figure 2). According to the latest census available, the Kisumu County accounted for 968,909 inhabitants of whom $49 \%$ are male and $51 \%$ are female, corresponding to 226,719 households (KNBS, 2017). Approximately $70 \%$ of the people live in rural areas and roughly $40 \%$ of people are poor (MoALF, 2017). In Kisumu agriculture plays a major role in economic growth, with small-scale production representing $90 \%$ of total agricultural production (MoALF, 2017). In 2012, maize crop was the largest contributor, accounting for $56 \%$ of the total food crop value (Kes 5.7 billion) (MoALF, 2017). Fertilizer use is low through the county: roughly $17 \%$ of farmers use organic manure, $5 \%$ basal fertilizer and $6 \%$ top dressing fertilizer; only a low percentage of farmers (2.6\%) use field pesticides and herbicides for select annual crops (MoALF, 2017). The rural area of Maseno is inhabited by Luo and Luhya communities who mainly adopt mixed farming systems: they cultivate maize and other crops such as cassava, potatoes, bananas, beans and rear livestock, primarily cattle but also goats, sheep and chickens. The push-pull system was developed as an integrated approach for managing stemborers, Striga weed and soil fertility, which are common problems in the area. Moreover, pushpull farming is based on locally available plants (Desmodium intortum and Napier grass) and fits well with traditional mixed cropping systems adopted by the communities involved in the study (Amudavi et al., 2009a, 2009b). Nevertheless, farmers using the push-pull system cultivate their land side-by-side with maize monoculture, hence its selection for the assessment of these contrasting approaches.

In order to explore and describe the effects of agroecological farming systems on smallholder livelihoods, a case study research method was chosen to provide a high level of detail on individuals or small groups within a specific context and to combine both quantitative and qualitative data (Yin, 2003). A case study was preferred over other research methods as it comprises a variety of approaches and means to collect and analyse data (Bartlett \& Vavrus, 2017), allowing the use of different techniques applied to small datasets, while producing solid results and findings (Riley \& Fielding, 2001; Small, 2011).

Before data collection, the field team held focus group discussions with farmers in order to: (a) ensure a common understanding of the objectives and the terms used in the assessment exercise; (b) select relevant indicators at household level belonging to several livelihood assets (DFID, 1999).

The farmer households were identified using the following criteria: type of farming systems (push-pull system vs conventional farming), family size (minimum two household components) and 


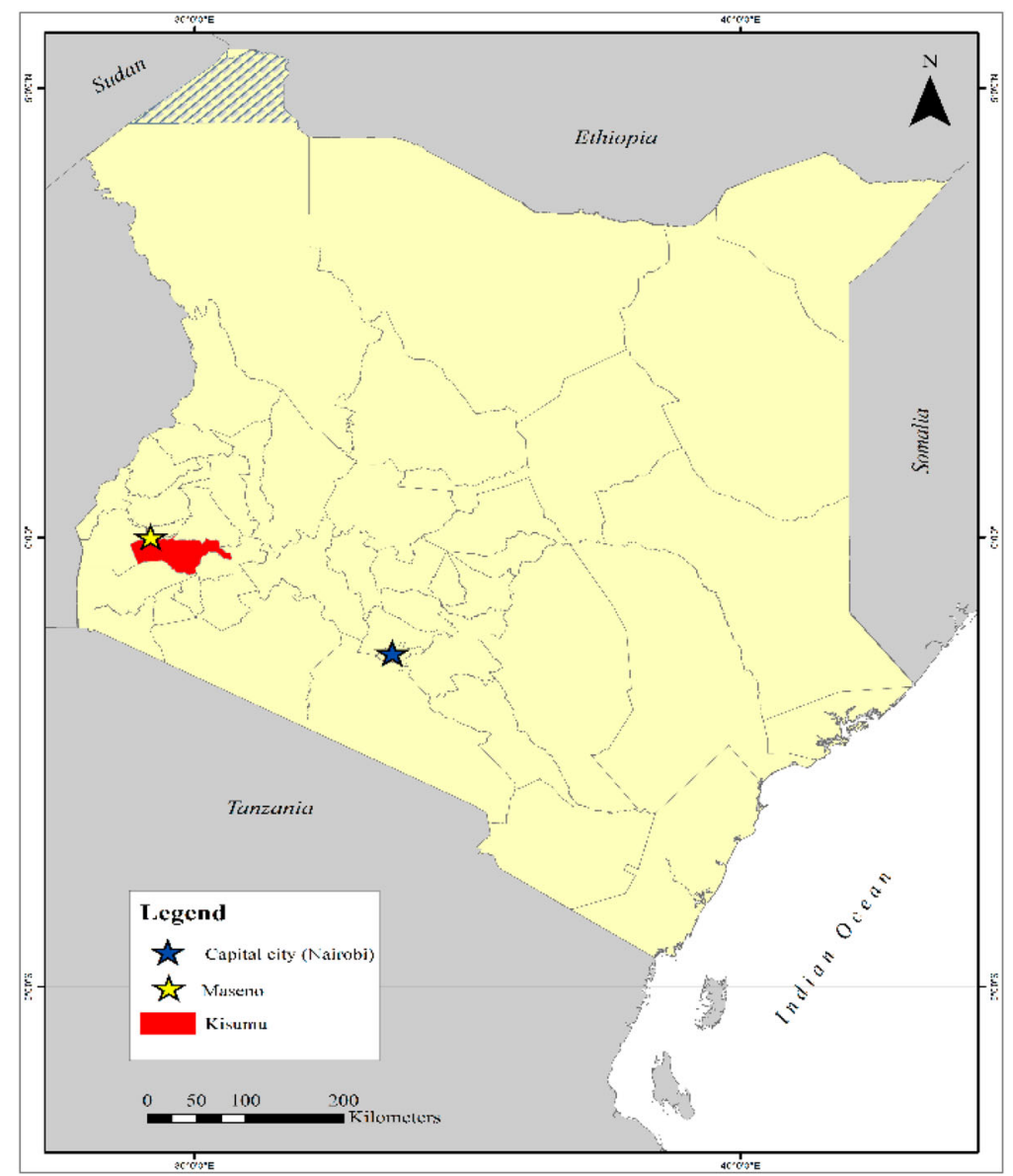

Figure 2. Map of study area in relation to Kenya.

availability to participate in the study. The list of farmers was shared by BvAT field-based officers who directly provide training to farmers. Due to a limited budget for this study, 23 farmers were identified as eligible, of which 11 were trained for the adoption of the push-pull system; 12 were applied conventional farming in maize production. The heads of farming households were interviewed by using a questionnaire composed of both closed-ended and openended questions and oral consents were obtained.

\subsection{Socioeconomic and ecological indicators}

The focus group discussions with farmers made it possible to identify relevant socioeconomic and ecological indicators (Table 1).

Therefore, the 18 selected indicators were classified according to the livelihood assets provided by the SL framework (DFID, 1999). The SL scheme has been largely used as a tool to analyse rural poverty from a multidimensional perspective (Baumann, 2002; Bennett \& Franzel, 2013; Garibaldi et al., 2016). However, SL framework has been modified according to the specific aim of the study in order to show the different effects at household level between agroecological and conventional farming system adoption. The four capitals were:

- Human/health: the competencies, knowledge and ability to work and healthy status that together enable farmers to pursue livelihood strategies and achieve personal and family goals.

- Social/cultural: the social resources (e.g. networks, affiliations) and cultural values (e.g. traditional practices) which farmers draw on in pursuit of their livelihood objectives.

- Natural/ecological: natural resource availability (e.g. livestock, land) and environmental services 
Table 1. Type and definition of the selected indicators.

\begin{tabular}{|c|c|c|c|}
\hline Capital & Indicator & $\begin{array}{l}\text { Type of } \\
\text { variable }\end{array}$ & Definition \\
\hline \multirow{6}{*}{$\begin{array}{r}\text { Human/ } \\
\text { health }\end{array}$} & Gender & Dummy & Sex of household head (male or female) ${ }^{a}$ \\
\hline & Household members & Discrete & Number of household components \\
\hline & Educational level & Discrete & Formal education attained by the head of household \\
\hline & Food worry & Dummy & Concern about food availability at household level \\
\hline & Skipped meal & Dummy & Access to sufficient food on a daily base \\
\hline & Sick last six months & Dummy & Presence of household member illness during the last six months \\
\hline \multirow[t]{4}{*}{ Social/cultural } & Extension services & Dummy & Availability of extensions services \\
\hline & Association & Dummy & Membership of a formal group \\
\hline & Group types & Dummy & Attribute of the affiliated group \\
\hline & $\begin{array}{l}\text { Cultural importance } \\
\text { practices }\end{array}$ & Dummy & Presence of animal and/or crop of cultural importance \\
\hline \multirow{5}{*}{$\begin{array}{l}\text { Natural/ } \\
\text { ecological }\end{array}$} & Crop diversity & Discrete & List of crop species on the farm \\
\hline & Livestock diversity & Discrete & List of animal species raised by farmer \\
\hline & Pest problems & Dummy & Presence of insect pests (e.g. stemborer) in maize crop \\
\hline & $\begin{array}{l}\text { Agroecological } \\
\text { practices }\end{array}$ & Discrete & Number of agroecological practices adopted by the farmer \\
\hline & Land size & Continuous & Dimension in hectares of the cultivated plot \\
\hline \multirow{3}{*}{$\begin{array}{l}\text { Financial/ } \\
\text { physical }\end{array}$} & Main source of income & Discrete & Major source of income for the household \\
\hline & Farm profitability & Continuous & $\begin{array}{l}\text { Difference between gross farm income (market value of the crops produced) and } \\
\text { expenses (sum of variable and fix costs of production) divided by the total area } \\
\text { under crops }\end{array}$ \\
\hline & Maize yield & Continuous & Amount of maize per hectare reported by farmer \\
\hline
\end{tabular}

${ }^{a}$ We use the indicator 'Gender' to identify the sex of the household head (male or female) responsible for carrying the main family business (e.g. crop cultivation). The indicator does not define the structure of the household or the socially ascribed, gender inequality between men and women.

provisions (e.g. pest control) together with the agroecological practices, which promote an equitable use of resources.

- Financial/physical: the main sources of financial capital, regular inflows of money (e.g. income, pensions) and available stocks (e.g. savings), that households use to improve their conditions.

\subsection{Data analysis}

Data were analysed using Generalized Linear Models (GLMs) in the R software (R Core Team, 2018). Each indicator was identified as an outcome variable $(y)$ in the GLM function, while the farming systems adopted by farmers were considered as a binary predictor $(x)$ of the estimated regression model (1):

$$
y=\beta 0+\beta 1 x+u
$$

In total, 18 simple linear regressions were run. Three probability distributions were used according to the types of outcome: binomial distribution for dummy variables, poisson and normal distributions for discrete and continuous variables (Table 1). GLM assumptions were checked and analysis of goodness-of-fit was performed with the pscl package (Jackman et al., 2019). The main results of the analysis, including means, proportions, standard errors and z/t scores, were summarized in Table 2 . In addition, a contingency table on the adoption of agroecological practices by farmer group was presented (Table 3 ). Finally, qualitative responses regarding the main reasons to adopt and the major benefits derived from the push-pull system were exhibited (Tables 4 and 5).

\subsection{Limitation of the study}

The small sample of selected farmers does not allow for the identification of significant relationships in several areas, and for this reason, the results on the adoption of the push-pull cannot be extensively generalized. However, the representativeness of the sample adopted was compared with other studies using a larger sample conducted in Western Kenya showing similar patterns. These studies use primary data collected through qualitative interviews, focus group discussions and questionnaires administrated to smallholders, in order to look at their farming systems holistically and provide a comprehensive overview of the implication on their social and economic welfare. Furthermore, quantitative results were triangulated with qualitative information from the research and outcomes from relevant studies on agroecology. This was done by comparing and 
mirroring similar contexts in which smallholder farmers operate with the aim to substantiate relevant findings and conclusions. The majority of smallholder farmers operate in the vast, diverse and risk-prone rainfed areas of the developing world, where their traditional farming systems cannot be easily reached by agricultural innovations. These farming systems are usually set in environments that are marginal for practicing intensive agriculture and are located in remote areas that are not always connected with markets and institutions. In this context, agroecological approaches are implemented through tailored farming practices, which are closely related to local resources, farmer knowledge and cultural values. The mentioned studies highlight that agroecological practices and systems are appropriate for smallholders in marginal environments, showing their contribution to poverty alleviation and environmental recovery.

\section{Results}

Overall, the age of the 23 heads of household interviewed ranged from 35 to 74 years old, with the majority of the households being male-headed (61\%). Female-headed households were mainly running push-pull (55\%) while fewer (25\%) were adopting conventional farming systems. The percentage of head of household who had not attained formal education was especially high in the case of push-pull farmers (PPFs) (55\%) compared to conventional farmers (CFs) (42\%). In terms of number of family members, the size was not the same between the two groups, reporting on average 5.5 for PPFs and 4.7 for CFs. The two groups mainly differed when considering the proportion of children and young adults ( $0-24 \mathrm{yrs}$ ) in households: $65 \%$ and $48 \%$ for PPFs and CFs respectively. Ninety-one percent of PPFs and $100 \%$ of CFs were concerned about food availability and $89 \%$ of PPFs and $91 \%$ of CFs regularly skipped meals. However, farmers reported to have sick members in their household: corresponding to $36 \%$ for PPFs and 33\% for CFs.

Agricultural extension services were usually available in the Maseno area: this was confirmed by farmer response, representing $82 \%$ for PPFs and $67 \%$ for CFs. The percentage of membership in formal groups was $73 \%$ for PPFs and $67 \%$ for CFs. The presence of culturally based practices (e.g. raising poultry for welcoming visitors) was lower for PPFs (64\%) than for CFs (100\%).
PPFs showed a higher number of cultivated crop species (4.7) compared to CFs (3.8), while the number of domesticated livestock species for PPFs and CFs was almost identical: 1.82 and 1.83. PPFs relied more on agricultural activities (100\%), while CFs diversified their income sources through off-farm activities such as remittance and other employment (16\%). On average, better agricultural performance was reported by the PPFs compared to CFs in terms of maize yield ( 384.4 vs $284.1 \mathrm{~kg} \mathrm{ha}^{-1}$ ) and farm profitability $(29,688$ vs $16,519.9$ Kes $)$.

As reflected in Table 2, two significant linear relationships were observed: group types and land size. In particular, $75 \%$ of PPFs were part of social groups compared to $13 \%$ of CFs (Figure 3). In order to estimate the goodness-of-fit of the model, the McFadden's pseudo R-squared was computed; the corresponding value was $31.5 \%$. The analysis identified another significant relationship between land size and farming system. PPFs cultivated smaller plots (1.9 ha) compared to CFs (3.1 ha) (Figure 3). With the aim of estimating the goodness-of-fit of the model, the Multiple R-squared was elaborated; the calculated amount was $23.3 \%$.

Although Table 2 showed that PPFs and CFs do not differ significantly in the number of agroecological practices adopted at field scale, Table 3 exhibited that PPFs mainly adopt practices where the main objective was to reduce the use of external inputs (55\%) and to sustain biodiversity (59\%); while CFs use practices aimed at promoting sustainable water use (52\%) (see Table A1 - Appendix). The same percentage was reported by respondents regarding the adoption of practices targeted to improve healthy soil (50\%) (Table 3).

As reflected in Table 4, farmers gave seven reasons which led them to adopt the push-pull farming system: $31 \%$ of farmers said to deal with the Striga weed; $19 \%$ mentioned increasing yield; another $19 \%$ highlighted access to extension services; $11 \%$ indicated reducing soil erosion; $8 \%$ cited the increase of fodder production; $8 \%$ referred to enhancing soil fertility; and finally $4 \%$ to control stemborer.

As presented in Table 5, farmers listed six benefits related to the adoption of the push-pull farming system. The greater number (30\%) of them mentioned a reduction in the Striga weed; $22 \%$ said increased yield; $13 \%$ indicated both enhanced soil fertility and increased animal feed; $11 \%$ cited reduced soil erosion and another $11 \%$ referred to improved quality of products. 
Table 2. Main results of the indicators collected for farmers adopting push-pull and conventional farming systems.

\begin{tabular}{|c|c|c|c|c|c|}
\hline Capital & Indicator & Unit & Push-pull mean (se) & Conventional mean (se) & $\begin{array}{c}\text { GLMs } \\
\text { z/t score }\end{array}$ \\
\hline \multirow[t]{6}{*}{ Human/health } & Gender & $\begin{array}{l}\text { Prop. } \\
\text { female }\end{array}$ & $0.55(0.15)$ & $0.25(0.13)$ & 1.422 \\
\hline & Household members & No. & $5.45(0.43)$ & $4.67(0.53)$ & -0.840 \\
\hline & $\begin{array}{l}\text { Educational } \\
\text { level }\end{array}$ & Prop. & $\begin{array}{l}\text { no education } 0.55(0.15) \\
\text { lower primary } 0.45(0.15) \\
\text { upper primary } 0(0)\end{array}$ & $\begin{array}{l}\text { no education } 0.42(0.14) \\
\text { lower primary } 0.50(0.14) \\
\text { upper primary } 0.08(0.08)\end{array}$ & 0.672 \\
\hline & Food worry & Prop. & $0.91(0.09)$ & $1(0)$ & 0.004 \\
\hline & Skipped meal & Prop. & $0.89(0.10)$ & $0.91(0.09)$ & 0.150 \\
\hline & Sick last six months & Prop. & $0.36(0.15)$ & $0.33(0.14)$ & -0.152 \\
\hline \multirow[t]{4}{*}{ Social/cultural } & Extension services & Prop. & $0.82(0.12)$ & $0.67(0.14)$ & -0.817 \\
\hline & Association & Prop. & $0.73(0.13)$ & $0.67(0.14)$ & -0.315 \\
\hline & Group types & $\begin{array}{l}\text { Prop. } \\
\text { economic }\end{array}$ & $0.25(0.15)$ & $0.87(0.12)$ & $-2.263^{*}$ \\
\hline & Cultural importance practices & Prop. & $0.64(0.15)$ & $1(0)$ & 0.006 \\
\hline \multirow[t]{5}{*}{ Natural/ecological } & Crop diversity & No. & $4.65(0.47)$ & $3.75(0.46)$ & -1.037 \\
\hline & Livestock diversity & No. & $1.82(0.57)$ & $1.83(0.53)$ & 0.027 \\
\hline & Pest problems & Prop. & $0.82(0.12)$ & $1(0)$ & 0.004 \\
\hline & Agroecological practices & No. & $15.3(1.2)$ & $13.7(0.6)$ & -1.012 \\
\hline & Land size & $\mathrm{Ha}^{\mathrm{a}}$ & $1.86(0.31)$ & $3.12(0.38)$ & $2.524^{*}$ \\
\hline \multirow[t]{3}{*}{ Financial/physical } & Main source of income & Prop. & $\begin{array}{l}\text { crop } 0.90(0.09) \\
\text { livestock } 0.10(0.09) \\
\text { remittance } 0(0) \\
\text { other employment } 0 \\
(0)\end{array}$ & $\begin{array}{l}\text { crop } 0.76(0.13) \\
\text { livestock } 0.08(0.08) \\
\text { remittance } 0.08(0.08) \\
\text { other employment } 0.08(0.08)\end{array}$ & 1.490 \\
\hline & Farm profitability & $\mathrm{Kes}^{\mathrm{b}}$ & $29,688.0(23,939.4)$ & $16,519.9(8,550.6)$ & -0.536 \\
\hline & Maize yield & $\mathrm{Kg} \mathrm{ha}^{-1}$ & $384.4(137.9)$ & $284.1(48.5)$ & -0.711 \\
\hline
\end{tabular}

Note: Statistically significant levels at ${ }^{*} p<0.05$. ${ }^{\mathrm{a}} \mathrm{Ha}=\mathrm{Hectare} ;{ }^{\mathrm{b}} \mathrm{Kes}=$ Kenyan shilling.

\section{Discussion}

The main quantitative results and the qualitative information are now discussed in light of relevant research studies on agroecology. Moreover, the main findings of the study are presented considering the main challenges and obstacles that limit the implementation of agroelcological practices in the broad SSA context.

Although we considered just 23 farmers in this study, household characteristics and availability of assets are similar to larger surveys conducted in Western Kenya, demonstrating the representativeness of our data. Those evidenced that more than $60 \%$ of the household head being male (Khan et al., 2008), the number of family members is approximately 5 (Kassie et al., 2018) and the cultivated plot size is normally less than 2.5 ha (Khan et al., 2008).

Farmers involved in the study have access to extension services which are provided in different ways: booklets, extension agents and mobile phone-based agricultural services. It is interesting to note that while PPFs have access to extension services provided by non-governmental organizations (90.9\%), the CFs mainly rely on government support (75\%). As shown in Table 4, the provision of extension services, which is mainly provided by field extension officers for PPFs, represents one of the main motivations for adopting push-pull (19\%). As demonstrated by Kassie et al. (2018), the probability of adopting the push-pull system tends to increase in accordance with farmer confidence in the skills of extension workers. As highlighted by Altieri (2002) and Mockshell and Villarino (2019), farmers often have low education levels and do not have access to adequate training services, therefore they are limited in their ability to efficiently adopt and implement agroecological systems which tend to be knowledge rather than input-intensive.

Table 3: Contingency table of adoption of agroecological practices (by main areas of contribution) and farmer groups.

\begin{tabular}{lllll}
\hline & Sustainable water use & Reduce external inputs & Promote healthy soil & Sustain biodiversity \\
\hline Push-pull farmers & $48 \%$ & $55 \%$ & $50 \%$ & $59 \%$ \\
Conventional farmers & $52 \%$ & $45 \%$ & $50 \%$ & $41 \%$ \\
\hline
\end{tabular}


Table 4. Main reasons clarified by farmers adopting push-pull system $(n=11)$.

\begin{tabular}{lr}
\hline Reason & $\%$ \\
\hline Deal with Striga weed & 31 \\
Increase yield & 19 \\
Extension service provision & 19 \\
Reduce soil erosion & 11 \\
Increase fodder production & 8 \\
Enhance soil fertility & 8 \\
Problem with stemborer & 4 \\
\hline
\end{tabular}

We found that farmers differ significantly on the types of groups of which they are members. Overall, 16 out of 23 farmers are part of formal groups. On the one hand, PPFs participate mostly in social groups (6 out of 8 ) that have education, training and spirituality as their main purposes. On the other hand, CFs take part in economic groups (7 out of 8) whose aim is to secure access to credit. PPFs are less exposed to economic burdens (e.g. loans) compared with farmers using conventional systems who need to borrow money in order to buy external inputs, such as pesticides and fertilizers. As underlined by several studies, indebtedness is one of the main causes of distress in the agricultural sector (Lerman, 2008; Sajjad et al., 2016). Socioeconomic factors, such as a decline in profits, increased production costs, market imperfections and low education levels are among the main causes of indebtedness for poor farmer households in particular (Gruère \& Sengupta, 2011; Merriott, 2017). PPFs show better social relationships at the community level, enhancing mutual trust and reciprocity, which can extend farmer influence on institutions. As showed by Amudavi et al. (2009a, 2009b), empowered farmers can actively participate and contribute to solving complex and interrelated challenges, such as poverty and hunger.

The average land size for the analysed farmers sample is less than 2.5 ha. However, PPFs differ significantly in land dimension compared to CFs: 1.9 and 3.1 ha, respectively. Although PPFs cultivate smaller plots, farm profitability is shown to be, on average, higher than CFs (Table 2). PPFs exhibit greater maize

Table 5. Main benefits reported by farmers adopting push-pull system $(n=11)$.

\begin{tabular}{ll}
\hline Benefit & $\%$ \\
\hline Diminished Striga weed & 30 \\
Increased yield & 22 \\
Enhanced soil fertility & 13 \\
Increased animal feed & 13 \\
Reduced soil erosion & 11 \\
Improved quality of crop & 11 \\
\hline
\end{tabular}

yield $\left(384.4 \mathrm{~kg} \mathrm{ha}^{-1}\right)$ compared to CFs (284.1 $\mathrm{kg} \mathrm{ha}^{-1}$ ). Moreover, while CFs tend to focus only on maize crop with a higher risk of harvest failure due to extreme weather events, PPFs usually intercrop maize with other crops such as beans and cassava generating a more stable income. Furthermore, PPFs produced a high quantity of fodder, which encourages them to engage in dairy activities. As shown in Table 3, PPFs mainly rely on practices where the aim is to reduce external input use (55\%) and sustain biodiversity (59\%). The adopted agroecological practices (e.g. on-farm production of animal feed) aim to support different components of the agroecosystem through the sustainable management of available resources and the promotion of ecosystem services (Garbach et al., 2017; Palomo-Campesino et al., 2018). As highlighted Garibaldi and PérezMéndez (2019) there is a link between agroecological practices which promote biodiversity-friendly landscapes and human wellbeing (e.g. job opportunities), and this needs to be better understood. It should be acknowledged that there is a high variability among the results collected for farm profitability and this might be attributed to different levels of knowledge in the implementation of the push-pull system (e.g. years of farming experience) and due to several constraints at the household level (e.g. budget).

One of the objectives of the introduction of the push-pull farming system in Western Kenya was to mitigate smallholder constraints (e.g. poor access to productive inputs and extension services) by using sustainable farming practices to help farmers improve cereal production while reducing the detrimental effects on the environment (e.g. use of agrochemicals) (Khan et al., 2008). As shown in Table 4, farmers provided several reasons for adopting the push-pull system. In particular, farmers reported the need: to deal with the Striga weed (31\%), to increase yield (19\%) and to gain access to extension services (19\%). As reported in Table 5, farmers emphasized several major benefits associated with the adoption of the push-pull system. Specifically, a reduction in the Striga weed (30\%), an increase in yield (22\%) followed by a high quantity of fodder (13\%) and enhanced soil fertility (13\%). The main benefits reported by PPFs, such as diminished Striga weed and increased soil fertility, are in line with the advantages reported in the scientific literature related to the adoption of the push-pull system and also coherent with the reasons that farmers provided for adopting this alternative system (Amudavi et al., 2009a, 

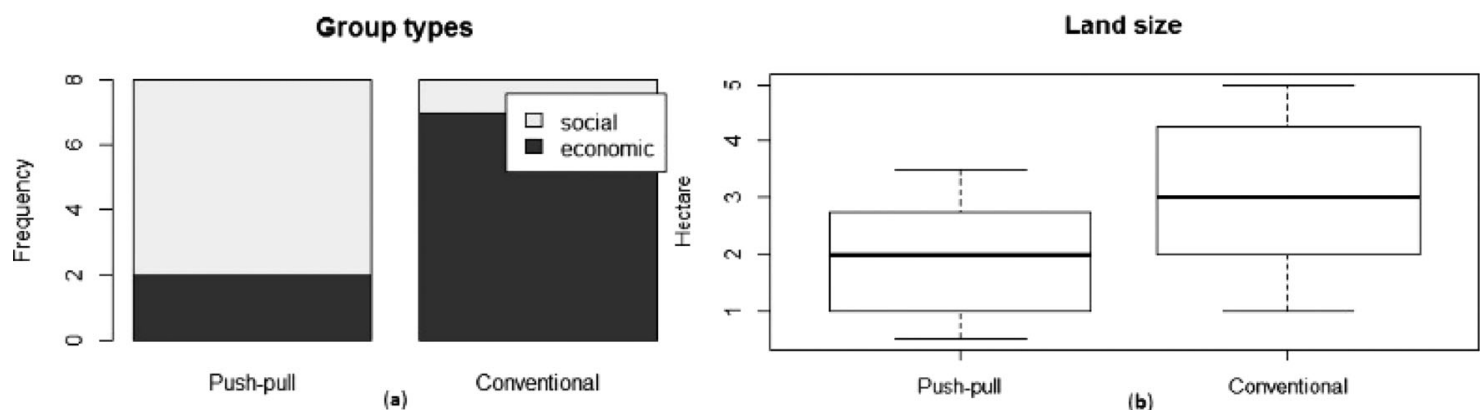

Figure 3. (a) Farmers' participation to social and economic groups (frequency). (b) Dimension of the cultivated plot by farming method (hectare).

2009b; Khan et al., 2011; Khan et al., 2016; Midega et al., 2015; Pickett et al., 2014, 2016). In addition, PPFs highlighted among the main benefits, the improved quality of crops. This is also confirmed by Mdee et al. (2019) which highlights that farmers adopting organic agriculture in Tanzania observed improvements in the quality of their farm product cultivated without the use of agro-chemicals.

According to Martiniello (2013) and Mockshell and Villarino (2019), there are policy and institutional challenges that limit the adoption of agroecological approaches in SSA. As shown by Jayne and Rashid (2013) and Mockshell and Birner (2015), many governments continue to promote policies mainly focused on modernizing the agricultural sector through the provision of input subsidies for chemical fertilizers. Furthermore, as reported by Martiniello (2013), a legal framework that recognizes access to land and secures land rights for smallholder farmers and indigenous minorities is also needed. Although the relationship between land tenure security and longterm investment in farming is complex, farmers usually avoid adopting agroecological approaches where the benefits are medium to long term (Isgren, 2016; Mockshell \& Villarino, 2019).

Poorly established institutions are a challenge for the adoption of agroecological practices. As suggested by Duru et al. (2015) participatory multi-actor approaches can be proposed as a strategy to better promote and sustain agroecological farming systems. These would include improved engagement with policy-makers, academia and civil society (Martiniello, 2017).

\section{Conclusions}

The adaptation and the implementation of the participatory assessment framework proposed by Garibaldi et al. (2017) offers an opportunity to promote the participation, learning and empowerment of farmers, in line with the comprehensive reframing of a development strategy in rural areas proposed by Altieri (2002) and Gliessman (2015). In addition, the adoption of the sustainable livelihood framework helps to identify in a holistic manner relevant patterns on farmer livelihood. Within this context, the push-pull system should be seen as a tool that mitigates smallholders' field constraints, and helps farmers to improve their livelihoods, including both material and social resources as opposed to the conventional maize monocropping system. As a result, this case study highlights the linkages between the adoption of push-pull system and related effects on social/cultural and natural/ecological capitals. Therefore, the push-pull system might represent an appropriate solution for resource-poor farmers especially in marginal lands that are less profitable for agricultural activities.

Although farmers adopting push-pull cultivate small land sizes, they have higher average maize yields and at the same time have multiple harvests, reducing detrimental environmental effects associated with the use of external inputs, without sacrificing farm profitability. Furthermore, they have better social relationships at the community level, enhancing mutual trust and reciprocity, which can extend farmer's influence over institutions, contributing to find better solutions to complex problems such as poverty and food security. However, it should be also noted that other selected indicators do not show statistically significant difference between the two farmer groups; this might be due to the fact that most of the farmers interviewed cultivate their land side-by-side sharing many similarities such as homogenous landscape and therefore reducing variability among the selected indicators. 
There is a strong relationship between the reasons to adopt push-pull farming system and the main benefits derived from this decision, highlighting those farmers' expectations are fulfilled and that the alternative system adopted is effective.

The promotion of agroecological approaches, such as the push-pull system, is affected by national policies and institutional challenges that limit their scaling-up in particular in the SSA countries. Considering the explorative nature of this study, the article makes a key contribution by pointing towards important questions for future research on agroecology. In this regard, we emphasize that:

- Farmers who cultivate small plot in the Maseno area have on average both higher maize yield and farm profitability than farmers who cultivate larger plot, pointing out the so-called inverse relationship (IR) between farm size and productivity. This might require future research aimed at providing more evidence on the benefits related to the push-pull farming system.

- There is a lack of evidence of interactive effects across practices; the combination of agroecological practices and their interactions would deserve further analysis in order to explore the potentiality of agroecological systems, going beyond the pushpull method.

- Indicators related to labour (e.g. labour productivity) should be systematically looked at in future analysis in order to understand the important aspect of affordability of the push-pull system in particular and of agroecological approaches in general.

- As agroecology promotes social integration and cohesion, a gender analysis should be systematically conducted in any research by collecting statistics disaggregated by sex and further qualitative information about socioeconomic conditions of men and women. This can certainly contribute to tackle gender inequality and at the same to value the role of agroecology as a contributing factor for social equity.

\section{Acknowledgements}

We would like to thank the two anonymous reviewers for their valuable comments and suggestions.

\section{Disclosure statement}

No potential conflict of interest was reported by the author(s).

\section{Funding}

This study was supported by the Doctoral School on the AgroFood System (Agrisystem) of the Università Cattolica del Sacro Cuore.

\section{Notes on contributors}

Raffaele D'Annolfo is a PhD in the Economics of Agro-Food System at the Università Cattolica del Sacro Cuore and a member of the Italian Association of Agricultural and Applied Economics. He held a Master's degree in Economics and Social Science $(3+2$ years) at theUniversità "La Sapienza" and is graduated with a second level Master's degree in Development Economics and International Cooperation at the University of Rome "Tor Vergata". He has several years of work experience in the field of research and development sector and collaborated with different international organizations (e.g. FAO) and NGOs in Ireland, Italy, Argentina, Ecuador and Uruguay. His main areas of interest are development economics, agroecology, rural poverty, livelihood assessment, social and economic analysis.

Barbara Gemmill-Herren is an Associate Faculty at Prescott College, Prescott, Arizona, USA and a Senior Associate to the World Agroforestry Centre, supporting the United Nations' work on agroecology and true-cost accounting in agriculture. She was Delivery Manager for Ecosystem Services and Biodiversity at the Food and Agriculture Organization of the United Nations (FAO), responsible for work on Ecosystem Services in Agricultural Production, and Agroecology. She was a project team member of the Committee on World Food Security of the UN, High-Level Panel of Experts Report on "Agroecological and other innovative approaches for sustainable agriculture and food systems that enhance food security and nutrition".

David Amudavi is the Director of Biovision Africa Trust and Coordinator of the Ecological Organic Agriculture Initiative for Africa. Dr Amudavi has a wide range of experience within the agricultural sector. Prior to joining BvAT he was a senior lecturer at the Egerton University in the Department of Agricultural Education and Extension. He has supervised many graduate students and published widely in international journals, contributed to book chapters, and presented several research papers at national and international conferences. He has also been involved in several international consultancies relating to livelihood improvement, technology transfer among smallholder farmers and strengthening of agricultural extension systems in SubSaharan Africa for various international organizations. David holds a PhD in Adult and Extension Education with minors in Developmental Sociology and Natural Resource Management (NRM) from Cornell University in the USA; MSc in Agricultural Science from The University of Melbourne University, Australia, and a BSC, in Agricultural Education and Extension from Egerton University, Kenya. Dr Amudavi was a postdoctoral fellow with ICIPE's Push-pull project: "Creating smallholder led growth through 'push-pull' technologies in Eastern Africa".

Hudson Shiraku, an environmental scientist, a blogger and a writer is a Project officer at the Biovision Africa Trust (BvAT) in charge of the Farmers' library; www.infonet-biovision.org. He has over 10 years of professional knowledge and experience in 
application of environmental considerations in agricultural projects management in Africa. Shiraku's multidisciplinary experience is spread in the domains of research, project cycle management, monitoring and evaluation, Climate Change adaptation and mitigation strategies, Environmental Impact Assessment and Audit, ICT for Development, content creation and management and creative writing. Shiraku has made conscious efforts to contribute towards improving the farmers' welfare by using his environmental expertise in bettering agriculture. To complement his excellent skills in team management, project/ program coordination, interdisciplinary research, he also attended 'formal' management and leadership training/courses.

Mariacristina Piva, PhD in Economics, is Full Professor of Economic Policy at the Università Cattolica del Sacro Cuore in Italy. She was Research Economist at the International Labour Organization (ILO) in Geneva. She has published her research in the fields of economics of innovation, industrial organization and labour economics in many refereed academic journals including Research Policy, Regional Studies, Small Business Economics and Contemporary Economic Policy. In addtion, she serves as referee for many international journals.

Lucas Garibaldi is the Director of the Research Institute on Natural Resources, Agroecology and Rural Development (IRNAD, UNRN-CONICET). His research focuses on topics such as agroecology, ecological economics, ecological intensification, pollination, and nature's contributions to people. He participates in inter-governmental scientific-political platforms, works with several associations of farmers and beekeepers, integrates institutional representations, and shares his research in different media, among other activities. He has travelled all the continents participating in numerous conferences and workshops, and generating important ties of cooperation. Dr Garibaldi's work aims to contribute towards a predictive science that allows preventing socio-environmental problems and proposing solutions.

\section{ORCID}

Raffaele D'Annolfo (iD http://orcid.org/0000-0002-3002-210X Barbara Gemmill-Herren (iD) http://orcid.org/0000-0003-4991640X

Mariacristina Piva (iD) http://orcid.org/0000-0002-3347-8946

Lucas A. Garibaldi (iD http://orcid.org/0000-0003-0725-4049

\section{References}

Altieri, M. A. (2002). Agroecology: The science of natural resource management for poor farmers in marginal environments. Agriculture Ecosystems \& Environment, 93(1-3), 1-24. https:// doi.org/10.1016/S0167-8809(02)00085-3

Altieri, M. A., \& Masera, O. (1993). Sustainable rural development in Latin America: Building from the bottom-up. Ecological Economics, 7(2), 93-121. https://doi.org/10.1016/0921-8009 (93)90049-C

Amudavi, D. M., Khan, Z. R., Wanyama, J. M., Midega, C. A. O., Pittchar, J., Hassanali, A., \& Pickett, J. A. (2009a). Evaluation of farmers' field days as a dissemination tool for push-pull technology in Western Kenya. Crop Protection, 28(3), 225235. https://doi.org/10.1016/j.cropro.2008.10.008
Amudavi, D. M., Khan, Z. R., Wanyama, J. M., Midega, C. A. O., Pittchar, J., Nyangau, I. M., Hassanali, A., \& Pickett, J. A. (2009b). Assessment of technical efficiency of farmer teachers in the uptake and dissemination of push-pull technology in Western Kenya. Crop Protection, 28(11), 987-996. https://doi. org/10.1016/j.cropro.2009.04.010

Balmford, A., Amano, T., Bartlett, B., Chadwick, D., Collins, A., Edwards, D., Field, R., Garnsworthy, P., Green, R., Smith, P., \& Waters, H. (2018). The environmental costs and benefits of high yield farming. Nature Sustainability, 1(9), 477-485. doi: https://www.ncbi.nlm.nih.gov/pubmed/30450426

Bartlett, L., \& Vavrus, F. (2017). Rethinking case study research a comparative approach. Taylor \& Francis: Oxon.

Baumann, P. (2002). Improving access to natural resources for the rural poor. A critical analysis of central concepts and emerging trends from a sustainable livelihoods perspective. FAO.

Bennett, M., \& Franzel, S. (2013). Can organic and resource-conserving agriculture improve livelihoods? A synthesis. International Journal of Agricultural Sustainability, 11(3), 193215. https://doi.org/10.1080/14735903.2012.724925

Berghöfer, A., Berger, J., Koné, I., Tröger, U., \& Caspary, H. U. (2018). Ecosystem services for conservation finance: Applying the TEEB stepwise approach in Côte d'lvoire. Biodiversity and Conservation, 11(11), 2897-2917. URL: https://www.springerprofessional.de/en/ecosystem-servicesfor-conservation-finance-applying-the-teeb-st/15863444. https://doi.org/10.1007/s10531-018-1576-0

Castañeda, A., Doan, D., Newhouse, D., Nguyen, M. C., Uematsu, H., \& Azevedo, J. P. (2018). A new profile of the global poor. World Development, 101, 250-267. https://doi.org/10.1016/j. worlddev.2017.08.002

Chepchirchir, R. T., Macharia, I., Murage, A. W., Midega, C. A. O., \& Khan, Z. R. (2018). Ex-post economic analysis of push-pull technology in Eastern Uganda. Crop Protection, 112, 356362. https://doi.org/10.1016/j.cropro.2018.07.001

D'Annolfo, R., Gemmill-Herren, B., Graeub, B., \& Garibaldi, L. A. (2017). A review of social and economic performance of agroecology. International Journal of Agricultural Sustainability, 15(6), 632-644. https://doi.org/10.1080/1473 5903.2017.1398123

De Groote, H., Owuor, G., Ouma, J. O., Muhammad, L., Danda, M. K., \& Doss, C. R. (2005). The maize green revolution in Kenya revisited. eJADE, 2, 32-49. https://core.ac.uk/download/pdf/ 6699557.pdf

Department for International Development (DFID). (1999). Sustainable livelihoods guidance sheets. DFID.

De Schutter, O. (2010). Agroecology and the right to food. UN.

Duru, M., Therond, O., \& Fares, M. (2015). Designing agroecological transitions; a review. Agronomy for Sustainable Development, 35(4), 1237-1257. https://doi.org/10.1007/ s13593-015-0318-x

Duru, M., Therond, O., Martin, G., Martin-Clouaire, R., Magne, M., Justes, E., Journet, E., Aubertot, J., Savary, S., Bergez, J., \& Sarthou, J. P. (2015). How to implement biodiversity-based agriculture to enhance ecosystem services: A review. Agronomy for Sustainable Development, 35(4), 1259-1281. https://link.springer.com/article/10.1007/s13593-015-0306-1

Foley, J. A., Ramankutty, N., Brauman, K. A., Cassidy, E. S., Gerber, J. S., Johnston, M., Mueller, N. D., O'Connell, C., Ray, D. K., West, P. C., \& Balzer, C. (2011). Solutions for a cultivated planet. Nature, 478(7369), 337-342. https://doi.org/10.1038/nature10452 
Food and Agriculture Organization of the United Nations (FAO). (2014). Country programming framework for Kenya 2014-2017. FAO.

Food and Agriculture Organization of the United Nations (FAO). (2018). FAO's work on agroecology: A pathway to achieving the SDGs. FAO.

Food and Agriculture Organization of the United Nations (FAO). (2019a). Food and agriculture data. Retrieved February 11, 2019, from http://www.fao.org/faostat/en/\#home

Food and Agriculture Organization of the United Nations (FAO). (2019b). GIEWS country brief Kenya. Retrieved January 10, 2019, from http://www.fao.org/giews/en/

Francis, C., Lieblein, G., Gliessman, S., Breland, T. A., Creamer, N., Harwood, R., Salomonsson, L., Helenius, J., Rickerl, D., Salvador, R., \& Wiedenhoeft, M. (2003). Agroecology: The ecology of food systems. Journal of Sustainable Agriculture, 22(3), 99-118. https://doi.org/10.1300/J064v22n03_10

Garbach, K., Milder, J. C., DeClerck, F. A. J., Montenegro, d. W., Driscoll, L., \& Gemmill-Herren, B. (2017). Examining multi-functionality for crop yield and ecosystem services in five systems of agroecological intensification. International Journal of Agricultural Sustainability, 15(1), 11-28. https://doi.org/10. 1080/14735903.2016.1174810

Garibaldi, L. A., Dondo, M., Hipólito, J., Azzu, N., Viana, B. F., \& Kasina, M. (2016). A quantitative approach to the socio-economic valuation of pollinator-friendly practices: A protocol for its use. FAO.

Garibaldi, L. A., Gemmill-Herren, B., D'Annolfo, R., Graeub, B. E., Cunningham, S. A., \& Breeze, T. D. (2017). Farming approaches for greater biodiversity, livelihoods, and food security. Trends in Ecology \& Evolution, 32(1), 68-80. https://doi.org/10.1016/J. TREE.2016.10.001

Garibaldi, L. A., \& Pérez-Méndez, N. (2019). Positive outcomes between crop diversity and agricultural employment worldwide. Ecological Economics, 164, 106358. https://doi.org/10. 1016/j.ecolecon.2019.106358

Gliessman, S. R. (2015). Agroecology: The ecology of sustainable food systems (3rd ed.). CRC press.

Gonthier, D. J., Ennis, K. K., Farinas, S., Hsieh, H., Iverson, A. L., Batáry, P., Rudolphi, J., Tscharntke, T., Cardinale, B. J., \& Perfecto, I. (2014). Biodiversity conservation in agriculture requires a multi-scale approach. Proc Biol Sci, 281(1791), 20141358. https://doi.org/10.1098/rspb.2014.1358

Graeub, B. E., Chappell, M. J., Wittman, H., Ledermann, S., Kerr, R. B., \& Gemmill-Herren, B. (2016). The state of family farms in the world. World Dev., 87, 1-15. https://doi.org/10.1016/j. worlddev.2015.05.012

Gruère, G., \& Sengupta, D. (2011). Bt cotton and farmer suicides in India: An evidence-based assessment. The Journal of Development Studies, 47(2), 316-337. https://doi.org/10.1080/ 00220388.2010 .492863

Hassan, R. M. (1998). Maize technology development and transfer: A GIS application for research planning in Kenya. CAB International, CIMMYT, KARI.

Hazell, P. B. R. (2009). The Asian Green Revolution. IFPRI.

Isgren, E. (2016). No Quick Fixes: Four Interacting constraints to advancing agroecology in Uganda. International Journal of Agricultural Sustainability, 14(4), 428-447. https://doi.org/10. 1080/14735903.2016.1144699

Jackman, S., Tahk, A., Zeileis, A., Maimone, C., Fearon, J., \& Meers, Z. (2019). Package 'pscl'. Retrieved June 22, 2019, from https:// cran.r-project.org/web/packages/pscl/pscl.pdf
Jayne, T. S., \& Rashid, S. (2013). Input Subsidy programs in subSaharan Africa: A synthesis of recent evidence. Agricultural Economics, 44(6), 547-562. https://doi.org/10.1111/agec. 12073

Kanampiu, F. K., Ransom, J. K., Friesen, D., \& Gressel, J. (2002). Imazapyr and pyrithiobac movement in soil and from maize seed coats to control Striga in legume intercropping. Crop Protection, 21(8), 611-619. https://doi.org/10.1016/S02612194(01)00151-X

Kassie, M., Stage, J., Diiro, G., Muriithi, B., Muricho, G., Ledermann, S. T., Pittchar, J., Midega, C., \& Khan, Z. (2018). Push-pull farming system in Kenya: Implications for economic and social welfare. Land Use Policy, 77, 186-198. https://doi.org/ 10.1016/j.landusepol.2018.05.041

Kebede, Y., Baudron, F., Bianchi, F., \& Tittonell, P. (2018). Unpacking the push-pull system: Assessing the contribution of companion crops along a gradient of landscape complexity. Agriculture Ecosystems \& Environment, 268, 115-123. https://doi.org/10.1016/j.agee.2018.09.012

Kenya National Bureau of Statistics (KNBS). (2017). Statistical Abstract. 2009. KNBS.

Khan, Z. R., Midega, C. A. O., Hooper, A., \& Pickett, J. (2016). Pushpull: Chemical ecology-based integrated pest management technology. Journal of Chemical Ecology, 42(7), 689-697. https://doi.org/10.1007/s10886-016-0730-y

Khan, Z. R., Midega, C. A. O., Njuguna, E. M., Amudavi, D. M., Wanyama, J. M., \& Pickett, J. A. (2008). Economic performance of the 'push-pull' technology for stemborer and Striga control in smallholder farming systems in Western Kenya. Crop Protection, 27(7), 1084-1097. https://doi.org/10.1016/j.cropro. 2008.01.005

Khan, Z., Midega, C., Pittchar, J., Pickett, J., \& Bruce, T. (2011). Push-pull technology: A conservation agriculture approach for integrated management of insect pests, weeds and soil health in Africa. International Journal of Agricultural Sustainability, 9(1), 162-170. https://doi.org/10.3763/ijas. 2010.0558

Lerman, Z. (2008). Farm debt in transition: The problem and possible solutions. FAO.

Martiniello, G. (2013). Land dispossession and rural social movements: The 2011 conference in Mali. Review of African Political Economy, 40(136), 309-320. https://doi.org/10.1080/03056 244.2013.797762

Martiniello, G. (2017). Agrarian politics and land struggles in Northern Uganda. Community Development Journal, 52(3), 405-420. https://doi.org/10.1093/cdj/bsx027

Mbeche Nyang'au, I., Kelboro, G., Hornidge, A. K., Midega, C., \& Borgemeister, C. (2018). Transdisciplinary research: Collaborative leadership and empowerment towards sustainability of push-pull technology. Sustainability, 10(7), 2378. https://doi.org/10.3390/su10072378

Mdee, A., Wostry, A., Coulson, A., \& Maro, J. (2019). A pathway to inclusive sustainable intensification in agriculture? Assessing evidence on the application of agroecology in Tanzania. Agroecology and Sustainable Food Systems, 43(2), 201-227. https://doi.org/10.1080/14735903.2016.1144699

Merriott, D. (2017). Factors associated with the farmer suicide crisis in India. Journal of Epidemiology and Global Health, 6 (4), 217-227. https://doi.org/10.1016/j.jegh.2016.03.003

Midega, C. A. O., Bruce, T. J. A., Pickett, J. A., Pittchar, J. O., Murage, A., \& Khan, Z. R. (2015). Climate-adapted companion cropping 
increases agricultural productivity in East Africa. Field Crops Research, 180, 118-125. https://doi.org/10.1016/j.fcr.2015.05.022

Ministry of Agriculture, Livestock and Fisheries (MoALF). (2017). Climate risk profile for Kisumu County. MoALF.

Mockshell, J., \& Birner, R. (2015). Donors and domestic policy makers: Two worlds in agricultural policy-Making? Food Policy, 55, 1-14. https://doi.org/10.1016/j.foodpol.2015.05.004

Mockshell, J., \& Villarino, M. E. (2019). Agroecological intensification: Potential and limitations to achieving food security and sustainability. In Encyclopedia of Food Security and Sustainability, Ferranti, P., Berry, E.M., Anderson, J.R.; Elsevier, 2019, 3, 64-70. https://doi.org/10.1016/B978-0-08-100596-5. 22211-7

Palomo-Campesino, S., González, J. A., \& García-Llorente, M. (2018). Exploring the connections between agroecological practices and ecosystem services: A systematic literature review. Sustainability, 10(12), 4339. https://doi.org/10.3390/su10124339

Pengue, W., Gemmill-Herren, B., Balázs, B., Ortega, E., Viglizzo, E., Acevedo, F., Diaz, D. N., Díaz de Astarloa, D., Fernandez, R., Garibaldi, L. A., Giampietro, M., Goldberg, A., Khosla, A., \& Westhoek, H. (2018). Eco-Agri-Food systems: Today's realities and tomorrow's challenges. In TEEB for agriculture \& food: Scientific and economic foundations (pp. 57-109). Geneve: UN Environment.

Pickett, J. A., \& Khan, Z. R. (2016). Plant volatile-mediated signaling and its application in agriculture: Successes and challenges. New Phytologist, 212(4), 856-870. https://doi.org/10. $1111 / \mathrm{nph} .14274$

Pickett, J. A., Woodcock, C. M., Midega, C. A., \& Khan, Z. R. (2014). Push-pull farming systems. Current Opinion in Biotechnology, 26, 125-132. https://doi.org/10.1016/j.copbio.2013.12.006

Poore, J., \& Nemecek, T. (2018). Reducing food's environmental impacts through producers and consumers. Science, 360(6392), 987-992. https://doi.org/10.1126/science. aaq0216

Pretty, J. (2008). Agricultural sustainability: Concepts, principles and evidence. Philos. Trans. R. Soc. Lond. B. Biol. Sci., 363 (1491), 447. doi:https://royalsocietypublishing.org/doi/abs/ 10.1098/rstb.2007.2163

Pretty, J., \& Bharucha, Z. P. (2015). Integrated pest management for sustainable intensification of agriculture in Asia and Africa. Insects, 6(1), 152-182. https://doi.org/10.1098/rstb.2007.2163

Pretty, J. N., Noble, A. D., Bossio, D., Dixon, J., Hine, R. E., De Vries, F. W. T. P., \& Morison, J. I. L. (2006). Resource-conserving agriculture increases yields in developing countries. Environmental Science and Technology, 40(4), 1114-1119. https://doi.org/10.1021/es051670d
R Core Team. (2018). R: A Language and environment for statistical computing. $\mathrm{R}$ foundation for statistical computing. Retrieved August 10, 2018, from https://www.r-project.org/

Riley, J., \& Fielding, W. J. (2001). An illustrated review of some farmer participatory research techniques. Journal of Agricultural Biological and Environmental Statistics, 6(1), 5-18. https://doi.org/10.1198/108571101300325210

Sajjad, H., Chauhan, C., Jamil, M., \& Srinagar, J. K. (2016). Indebtedness and its causal factors among farmers in Sangroor District, Punjab: A household level analysis. Transactions, 38, 101-115. Retrieved April 22, 2019, from https://pdfs.semanticscholar.org/9469/fa284bcfe8c87912e96 77784803813324610.pdf

Schader, C., Grenz, J., Meier, M. S., \& Stolze, M. (2014). Scope and precision of sustainability assessment approaches to food systems. Ecology and Society, 19(3), 1-15. https://doi.org/10. 5751/ES-06866-190342

Secretariat of the Convention on Biological Diversity (SCBD). (2014). Global biodiversity outlook 4. SCBD.

Small, M. L. (2011). How to conduct a mixed methods study: Recent trends in a rapidly growing literature. Annual Review of Sociology, 37(1), 57-86. https://doi.org/10.1146/annurev. soc.012809.102657

Speelman, E. N., López-Ridaura, S., Colomer, N. A., Astier, M., \& Masera, O. R. (2007). Ten years of sustainability evaluation using the MESMIS framework: Lessons learned from its application in 28 Latin American case studies. International Journal of Sustainable Development \& World, 14(4), 345-361. https:// doi.org/10.1080/13504500709469735

United Nations (UN). (2015). Transforming our World: The 2030 Agenda for Sustainable Development. Retrieved June 10, 2016, from https://sustainabledevelopment.un.org/post2015/ transformingourworld

Wezel, A., Goris, M., Bruil, J., Félix, G., Peeters, A., Bàrberi, P., Bellon, S., \& Migliorini, P. (2018). Challenges and action points to amplify agroecology in Europe. Sustainability, 10(5), 1598. https://doi.org/10.3390/su10051598

World Bank (WB). (2019). World development indicators. Retrieved April 29, 2019, from https://data.worldbank.org/country

Xinchun, C., Mengyang, W., Xiangping, G., Yalian, Z., Yan, G., Nan, W., \& Weiguang, W. (2017). Assessing water scarcity in agricultural production system based on the generalized water resources and water footprint framework. Science of the Total Environment, 609, 587-597. https://doi.org/10.1016/j. scitotenv.2017.07.191

Yin, R. K. (2003). Case study research: Design and methods (2nd ed.). SAGE. 


\section{Appendix}

Table A1. Twenty-six agroecological practices were considered in the analysis according to four main areas of contribution.

\begin{tabular}{|c|c|c|c|}
\hline $\begin{array}{l}\text { Sustainable water use } \\
(n=4)\end{array}$ & $\begin{array}{l}\text { Sustain biodiversity } \\
\qquad(n=8)\end{array}$ & $\begin{array}{l}\text { Promote healthy soil } \\
\qquad(n=6)\end{array}$ & $\begin{array}{l}\text { Reduce external inputs } \\
\qquad(n=8)\end{array}$ \\
\hline Contour farming & Intercropping & Green manure & Alternative weed control \\
\hline $\begin{array}{l}\text { Grass stripping/living } \\
\text { barriers }\end{array}$ & $\begin{array}{l}\text { Seed saving \& recovery of local } \\
\text { varieties }\end{array}$ & Compost application & Integration of crops \& livestock \\
\hline Terracing & Cultivation of medicinal plant & Minimum tillage & $\begin{array}{l}\text { On-farm production of animal feed and } \\
\text { pasture }\end{array}$ \\
\hline \multirow[t]{5}{*}{ Rain harvesting } & Local variety mixtures & $\begin{array}{l}\text { Organic soil } \\
\text { amendments }\end{array}$ & Limited field burning \\
\hline & Coppicing & Crop rotation & On-farm nurseries \\
\hline & Living fence posts \& hedgerows & Cover cropping & Mulching \\
\hline & Reforestation & & Artisanal food processing \\
\hline & Diversification with fruit trees & & Improved animal traction \\
\hline
\end{tabular}

